\title{
Complexity and Significance: A Sequential Analysis on the Conduct of Research
}

\author{
Kingie G.Micabalo ${ }^{1}$, Jesszon B.Cano ${ }^{2}$, Ryan D.Montilla ${ }^{3}$, Arsenio Robert N.Tan ${ }^{4}$ and June Ace P.Navarro ${ }^{5}$ \\ ${ }^{1,3,4 \& 5}$ Business and Accountancy, University of Cebu, Philippines \\ ${ }^{2}$ Hospitality Management, Bohol Island State University, Candijay, Philippines \\ E-mail: kmicabalo@uc.edu.ph, jesszon.cano@bisu.edu.ph,rmontilla@uc.edu.ph, artan@uc.edu.ph, janavarro@uc.edu.ph
}

\begin{abstract}
Research is a mission for trust with the assistance of study, acknowledgment, association, and preliminaries in the journey for information through the goal and proficient methodology to discover answers for an issue. The examination decides and breaks down the degree of appraisal seen by the understudies as far as the complexity and significance of the research. The examination respondents were the 252 understudies from Marketing and Human Resource Management courses utilizing the descriptive survey method as a research instrument on a simple random sampling. Frequency and simple percentage, and Mode were used to summarize, separate, and unravel the information. The discovery uncovered that understudies gigantically experienced complexities recorded in composing the proposition, leading the exploration, and managing the research paper. The study concludes that research is a critical portion of understudies' learning cycle and incredibly adds to making College undertaking more compelling in imparting long lasting learning. Departmental Research courses and workshops are to be practiced to hone understudies' degree of commitment and mindfulness concerning Research. Emphasis on the significance of research among understudies is a thing to be perceived to persuade them to seek after research, notwithstanding the struggles that they may experience.

Keywords: Business Administration, Research, descriptive study, Mandaue City, Philippine
\end{abstract}

\section{INTRODUCTION}

Research is an imperative area is not just in the area of education but also in other fields. It purifies the workings of an individual. It primarily focuses on improving quality and is a search for knowledge. It shows how to make provision of solutions to problems scientifically and methodically. It is a systematic effort to acquire new knowledge in all disciplines (Kapur, 2018).

As Kothari (2004) indicated, Research is a quest for trust and information through the target and systematic method for achieving an issue's answers. Understudy point of view of undertaking an examination venture is investigated. Inspirations for point decisions incorporate individual premium, vocation desires, and straightforward entry to essential information or the writing obstructions in the exploration cycle by understudies, such as information assortment and access issues (Lanson, 2004). Quantitative Research: Quantitative specialists need to configuration proportions of builds like dread, insightfulness, or happiness to give exact and important factual outcomes. Qualitative
Research: Qualitative examination includes nonmathematical data and fundamentally happens through meetings. The affirmation of truth claims includes rationale and strategies, which may not be emphatically fitting (Pramodini \& Sophia, 2012).

In the investigation of Joosten et al. (2016), challenges in the leading examination were explicitly recognized as follows; Incentivizing participation: Given the financial atmosphere impacting numerous institutional assets, money related motivations are impossible, or the boost brings about negligible cooperation-reliance on self-reported data. Similarly, as with any exploration attempt, including people's conclusions and practices, dependence on selfannounced information implies our information is 'comparable to the reactions we request. Exploration is group-based; however, there is an attendance of culture. Research inside the territory of separation training regularly requires a collective endeavor to be led successfully.

However, numerous foundations do not energize group based ventures, which is frequently evident in the absence of assets that would empower divergent people to impart and cooperate on one undertaking. They are getting to superior level information. Superior level information is regularly necessary for directing a thorough observational examination. Singular level information, which means data and information at the understudy's degree, is harder to get to, yet essential while inspecting specific populaces and understudy results. Numerous specialists show the trouble of finishing quality exploration without fundamental assets.

These assets incorporate financial pay, workforce and understudy members, information on robust examination plan, and a nonappearance of an open space where scientists can help each other just as team up on comparative ventures. Understudies are confronting study weariness. A significant number of the separation instruction research ventures incorporate studies as a social occasion information method; understudies show dissatisfaction as they approach to partake in this type of information assortment-weight for disciplinary examination versus Research on educational practices. A test needs to create Research that concentrates on a particular scholarly control instead of a spotlight on general academic methods that can illuminate quality instruction and schooling. More 
generalizable and widespread exploration is required to separate education and instructional practices. They are adjusting review inquiries with research questions. Interpreting the thoughts in an exploration question into a substantial, quantifiable, and quantifiable component is no simple assignment that frequently requires a subtle harmony between consolidating recently settled operationalization in the field and declaring new ones (Sekaran, \& Bougie, 2016).

As per Cabral, \& Huet (2011), the exploration for the nature of instructing and understudy learning and, through the assortment of acceptable practices and proposals, contend for the mix of these research assessment structures. It demonstrates the need to educate, proficient staff turn of events, evaluation measures, and the effect of exploration on graduate/postgraduate understudy learning. By the introduced circumstance, the advocate who is in the field of academe encouraging Business and Management discipline, an employee, Program Research Coordinator, and a Marketing Research subject Instructor will decide and analyze the level of perception as to understudy's (i) composing the proposition(ii) leading the examination, (iii) writing the exploration paper and the significance of Research the College of Business and Accountancy. By the exploration directed, the analyst will prescribe an Intervention Scheme to advance continuous improvement.

\section{FRAMEWORK}

The study was anchored on Program Theory, which gives an intelligible image of how change happens and how to improve execution. The Program Theory tells the best way to create, speak to, and use program hypothesis mindfully and deliberately to suit a specific situation (Funnell, and Rogers, 2011). Program hypothesis as a bunch of express or verifiable suppositions by partners about what activity is needed to fathom a social, instructive, or medical issue and why the difficult will react to this activity (Chen, 2012). Program Theory's motivation is not just to survey whether mediation works or does not work, but also how and why it does. The data is necessary for partners to improve existing or future projects (Chen, 2012). Program hypothesis is a deliberate setup of partners' prescriptive presumptions and clear suspicions of entire projects, regardless of whether unequivocal or understood (Donaldson, 2012).

It is further upheld by Action Model, which is a deliberate arrangement for orchestrating staff, assets, settings, and backing associations to arrive at an objective gathering and convey mediation administrations (Saunders, 2015). Projects are messy wonders, for the most part resulting from experience and expert legend. At the same time, mentioning an assessment, partners need to know whether they are doing works and improving the mediation (Chen, 2012). Convictions and recognition are the roots or establishments of the person's perspective. It is the channel of any info dependent on a person's convictions (Teknomo, 2006). A powerful dynamic necessitates that subject's structure and maintains a belief about choices' correctness, a metacognition process in a dubious and uncertain world. Prediction of future outcomes and self-monitoring are only useful if opinion closely matches behavioral performance (Drugowitsch, J. et al., 2014).

As indicated by David (2002), understudies are not continually sitting inactively before a teacher in present-day study halls; understudies challenge each other to recall realities or make a rundown toward the finish of class of the central facts they discovered. Being express about desires can likewise help control understudies the correct way a great utilization of metacognition inside Bloom's scientific classification. Thus, assist understudies with assuming liability for their own learning (Anderson et al., 2001). Crowe et al., (2008), Most resources would concur that scholarly achievement ought to be estimated not only regarding what understudies can recollect, yet what understudies can do with the information.

The Theory of Change also strengthens the investigation by Weiss (2019), an extensive portrayal and outline of how and why an ideal change must occur in a specific setting. It is explicitly centered, delineating the "missing center" between what projects or change activity does (its exercises or intercessions) and how they wanted to accomplish objectives. As per Roulstone et al. (2015), the Outcomes Framework at that point gives the premise to distinguish what sort of action or intercession will prompt the results recognized as preconditions for accomplishing the drawnout objective. It produces better orchestrating, in that activities are associated with a low down understanding of how change happens.

Upheld by Maini et al. (2017), expressing the development of a Theory of Change ordinarily happens through a consultative cycle, expecting partners to ponder how projects can achieve change. ToCs help cause unequivocal any hidden suspicions, to recognize the part of setting and give proof to legitimize the chain of causal pathways.

Systems Theory of Mead (2019) further backs the examination. It is an interdisciplinary investigation of frameworks with a potent combination of interrelated and reliant parts that are either common or human-made. Each framework portrays its spatial and transient limits, encircled and impacted by its current circumstance, depicted by its structure and reason or nature, and communicated in its working.

In the investigation of Foster et al. (2007), frameworks change arisen as a predominant edge through which nearby state and public funders and specialists over a complete cluster of fields approach people to work. As per Miller (2017), frameworks have upgraded both the instructors and the understudies' presentation. Using innovation, the school, the executives, and the educators can get information to guide the most proficient method to improve the understudies' exhibition. 


\section{OBJECTIVES OF THE STUDY}

The investigation was meant to decide the level of Complexity as saw by the understudies regarding: (i) setting up the proposition, (ii) leading the exploration, (iii) composing the research paper, and the significance of directing Research.

It also looks to propose activities that would ingrain in the College of Business and Accountancy the undergrad research energy. Inspire understudies to seek after Research, notwithstanding the difficulties that they may experience. This investigation filled in as the reason for a Sustainable Intervention Plan to guarantee its pertinence to the understudies' current and future necessities. In particular, it recognizes the respondents' profile as far as age, sexual orientation, legal status, course major, and year level. It tries to decide and break down the degree of recognition as to the complexity and significance of research.

\section{MATERIALS AND METHODS}

\section{A. Research Environment}

The exploration was led at the University of Cebu LapuLapu and Mandaue grounds situated at A.C. Cortes Ave., Mandaue City. It offers Accountancy, Bachelor of Science in Business Administration, with four majors: Management Accounting, Marketing Management, Financial Management, and Human Resource Development Management.

\section{B. Research Respondents}

The exploration study devised 252 respondents from the Marketing and Human Resource Development and Management course utilizing Slovin's formula to determine the study's sample size on a simple random sampling method.

\section{Research Instrument}

The investigation utilizes the descriptive survey method and self-built study poll. The instrument is made out of two parts. The initial segment is the respondent's profile and the second part is the level of perception on (I) setting up the proposition, (ii) leading the exploration, (iii) composing the examination paper, and the significance of directing inquiry.

\section{Treatment of Data}

Frequency and simple percentage, along with Mode, was used to treat the accumulated data.

TABLE I OF RESPONDENTS PER YEAR LEVEL
\begin{tabular}{|l|c|r|}
\hline Year Level & f & Percentage \\
\hline $3^{\text {rd }}$ Year & 147 & 58.00 \\
\hline $4^{\text {th }}$ Year & 105 & 42.00 \\
\hline Total & 252 & 100.00 \\
\hline
\end{tabular}

Table II shows the number of respondents every year utilizing simple random sampling as the information gathering procedure.

\section{E. Research Procedure \\ 1. Data Gathering}

To accomplish the examination, a letter of expectation tended to the Dean of the College of Business and Accountancy for information gathering, asking permission to direct the survey. The polls were controlled actually by the proponent and through Google form. The information was being organized and investigated. A boundary used to decipher the reactions:

TABLE II PARAMETERS FOR INTERPRETATION

\begin{tabular}{|c|l|l|}
\hline Modes & Ratingscheme & \multicolumn{1}{|c|}{ Interpretation } \\
\hline 4 & Strongly Agree & $\begin{array}{l}\text { There was evidence that the } \\
\text { indicators were performed in all } \\
\text { cases. }\end{array}$ \\
\hline 3 & Agree & $\begin{array}{l}\text { There was evidence that the } \\
\text { indicators were performed in many } \\
\text { cases. }\end{array}$ \\
\hline 2 & Disagree & $\begin{array}{l}\text { There was evidence that the } \\
\text { indicators were performed in a few } \\
\text { cases. }\end{array}$ \\
\hline 1 & $\begin{array}{l}\text { Strongly } \\
\text { Disagree }\end{array}$ & $\begin{array}{l}\text { There was no evidence that the } \\
\text { indicators were performed at all. }\end{array}$ \\
\hline
\end{tabular}

Frequency and Simple Percentage: To sum up and investigate the respondents' profile regarding age, sexual orientation, legal status, course major, and year level. Mode, to analyze the information fair and square of appraisal as seen by the students in conducting research.

\section{RESULTS AND DISCUSSION}

This section presents the consequences of the information accumulated in the respondent's profile. The next part shows the level of complexity and significance of conducting research.

TABLE III PROFILE OF THE RESPONDENTS (N = 252)

\begin{tabular}{|c|c|c|}
\hline & Frequency & Percentage \\
\hline \multicolumn{3}{|l|}{ Age } \\
\hline $20-21$ & 91 & 36 \\
\hline $22-23$ & 91 & 36 \\
\hline 24-above & 70 & 28 \\
\hline \multicolumn{3}{|l|}{ Sex } \\
\hline Male & 71 & 28 \\
\hline Female & 181 & 72 \\
\hline \multicolumn{3}{|c|}{ Civil Status } \\
\hline Single & 242 & 96 \\
\hline Married & 10 & 4 \\
\hline \multicolumn{3}{|c|}{ Course Major } \\
\hline MM & 151 & 60 \\
\hline HRM & 101 & 40 \\
\hline
\end{tabular}


Table III shows the profile of the College of Business Administration understudy subject to age, sex, legitimate status, and course major. It shows respondents who developed at 20-23 years old who got the most noteworthy equivalent at $72 \%$.This information infers that the understudies in CBA are at the youthful grown-up's stage. They were upheld by the Education State University (2019), expressing that the Philippines' Higher training is firmly in the private area. Most four-year college educations are for a very long time. Understudies are generally from 17 to 20 years of age. Concerning sexual orientation, a more significant part of $79 \%$ of the respondents on the College of Business and Accountancy were female. It pictures out that the female has more tendencies to take the College of Business and Accountancy projects.

Concerning the legal status, a larger part of the respondents was single or equal to $96 \%$. The chances that a student is single has involvement in exploration and composing papers, have no different obligations, in great mental and actual wellbeing, and can keep up a full course burden and examination simultaneously infers that the understudy is viable and productive. Concerning the course major, most were Marketing Management major with a sum of $60 \%$. It infers that the vast majority of the College of Business and Accountancy understudies decide to go through the program. As per Siu (2017), a degree in marketing is a keen thought accomplishment in promoting a four-year college education in a few fields. However, a marketing degree makes it simpler to find a passage level work and ascend in the area quicker.

Ultimately, business organization majors may become familiar with the administrative side of the business world. Notwithstanding seminars on the fundamentals of advertising, they additionally figure out how to oversee individuals, cycles, and financial plans. Marketing is a fascinating order regarding space for both imaginative sorts in the program and Marcom office, just as the systematic kinds in the business insight and examination office. Contingent upon interests and characteristic blessings can follow either way to a fruitful advertising vocation Siu, (2017).

TABLE IV LEVEL OF ASSESSMENTON THE SIGNIFICANCE OF RESEARCH UNDERTAKING REVEALED BY THE RESPONDENTS

\begin{tabular}{|c|c|c|c|c|}
\hline Significance of Research Undertaking & Mode & Interpretation & $(\%)$ & Rank \\
\hline It gives a logical and hypothetical premise. & 3 & Agree & 70 & 1 \\
\hline It permits organizing and reviewing much material. & 3 & Agree & 68 & 2 \\
\hline It gives information on motivations behind critical thinking and dynamic. & 4 & Strongly Agree & 66 & 3 \\
\hline It builds up an impressive level of certainty. & 3 & Agree & 64 & 4 \\
\hline It gives practice in the particular assortment, investigation, and detailing of data. & 4 & Strongly Agree & 64 & 4 \\
\hline $\begin{array}{l}\text { It characterizes the boundaries and recognizes the limits of the field of } \\
\text { specialization. }\end{array}$ & 3 & Agree & 62 & 5 \\
\hline It portrays the qualities of the circumstance about which little is known. & 3 & Agree & 62 & 5 \\
\hline $\begin{array}{l}\text { It gives involvement with arranging Research over an all-encompassing period } \\
\text { and fulfilling a time constraint. }\end{array}$ & 3 & Agree & 62 & 5 \\
\hline $\begin{array}{l}\text { It assembles information or data on circumstances or conditions about which } \\
\text { little information is accessible. }\end{array}$ & 3 & Agree & 52 & 6 \\
\hline $\begin{array}{l}\text { It gives dynamic learning through the recognizable proof of an issue to be } \\
\text { investigated and finished. }\end{array}$ & 3 & Agree & 58 & 7 \\
\hline It causes us to gain the capacity to characterize and examine a perplexing issue. & 4 & Strongly Agree & 58 & 7 \\
\hline It empowers ability improvement for autonomous examination. & 3 & Agree & 56 & 8 \\
\hline $\begin{array}{l}\text { It creates and assesses hypotheses and ideas and practices for lucidity and } \\
\text { legitimacy. }\end{array}$ & 3 & Agree & 56 & 8 \\
\hline It gives a logical information base from which speculations arise and are created. & 3 & Agree & 54 & 9 \\
\hline $\begin{array}{l}\text { It reports the social pertinence and adequacy of the field of specialization to } \\
\text { individuals and society. }\end{array}$ & 3 & Agree & 54 & 9 \\
\hline It empowers understudies to satisfy the prerequisites of the course & 4 & Strongly Agree & 54 & 9 \\
\hline It remedies, explains, and approve discernments. & 4 & Strongly Agree & 52 & 10 \\
\hline It upgrades diagnostic critical thinking aptitudes. & 3 & Agree & 50 & 11 \\
\hline It supports the mix of scholarly information and viable application. & 3 & Agree & 50 & 11 \\
\hline $\begin{array}{l}\text { It gives a closer communication with the examination group (co-researchers and } \\
\text { employees) }\end{array}$ & 4 & Strongly Agree & 50 & 11 \\
\hline Overall Mode & 3 & Agree & & \\
\hline
\end{tabular}


Table IV shows the outcomes on the Level of Assessment on the Importance of Undertaking Research as uncovered by the Respondents. The pointer that gives the logical and

hypothetical premise recorded the most noteworthy Mode at $70 \%$ and deciphered as Agree. It infers that when directing exploration, understudies accept that it gives analytical and theoretical speculation. As per Ahmad (2016), Research is an "efficient examination, including research advancements, testing and assessment, intended to create or add to generalizable information." It likewise intends to set up realities and arrive at new resolutions.

Upheld by Story (2013), which expresses that the preferred position of being a functioning analyst is a commitment to current instruments and innovation.

Understudies moving on from school today have accessible actual devices, for example, tablet PCs and new programming that was unbelievable a couple of years prior, significantly less than ten years back.

Reddy (2019) expresses that Research intends to examine the issues painstakingly or do the nitty-gritty investigation of the particular problems by utilizing extraordinary logical techniques. Exploration should be possible on any subject, be it clinical, non-clinical, IT, or whatever else.

As to indicator, it enhances analytical problem-solving skills. It recorded the lowest Mode at 50\% and interpreted as Agree. Indicator: encourages the integration of academic knowledge and practical application, re-recorded the lowest Mode at 50\%, and interpreted as Agree.

The last marker, which expresses that examination, gives a closer communication the exploration group (co-analysts and employees), got the most reduced Mode likewise at the half and deciphered as Strongly Agree.

The pointers expressed above suggest that the markers in directing Research are significant; however, these territories should upgrade for it got the least translation since half of the respondents concurred about its essentialness.

Umbach \& Wawrzynski (2005) indicated that understudies report more elevated levels of commitment and learning at establishments where employees utilize dynamic and cooperative learning. Connections had considerable constructive outcomes on understudy's endeavors in other instructively intentional exercises, which had noninsignificant impacts on the assessed additions and fulfillment (Kuh, and $\mathrm{Hu}, 2001$ ).

Communitarian research centers principally on the viewpoints, interests, and needs of members, necessitating that these members impact the whole exploration measure, from venture plan, information social event, and information examination, to the introduction of eventual outcomes (Lassiter, 2005).
It includes a close idea of scholarly investigation and practice-based proficiencies, and the advancement of procedures to weave them together (Jeannotte \& Duxbury, 2015).

Practice-based assessment implies that questions and approaches emerge through creation, doing, and testing things (Hope, 2016).Upheld by Duxbury et al. (2019), itemizing that problems have arisen of how corresponding connections are kept inside an exploration and-application venture, how the training side of the undertaking can be taken care of, and how the information co-made in this cycle can profit the two specialists and experts.

\section{TABLE V LEVEL OF ASSESSMENT ON THE COMPLEXITY IN SETTING UP THE PROPOSITIONAS REVEALED BY THE RESPONDENTS}

\begin{tabular}{|l|c|c|c|c|}
\hline $\begin{array}{l}\text { Complexity in } \\
\text { setting up the } \\
\text { proposition }\end{array}$ & Mode & Interpretation & (\%) & Rank \\
\hline $\begin{array}{l}\text { Being acquainted } \\
\text { with different } \\
\text { investigations in } \\
\text { regions identified } \\
\text { with the field of } \\
\text { specialization }\end{array}$ & 3 & Agree & 72 & 1 \\
\hline $\begin{array}{l}\text { Building up the } \\
\text { estimation of the } \\
\text { issue to society and } \\
\text { expertise }\end{array}$ & 3 & Agree & 72 & 1 \\
\hline $\begin{array}{l}\text { Setting up complete } \\
\text { literature of the } \\
\text { writing }\end{array}$ & 3 & Agree & 70 & 2 \\
\hline $\begin{array}{l}\text { Choosing a } \\
\text { researchable and } \\
\text { plausible case or } \\
\text { inquiry }\end{array}$ & 3 & Agree & 66 & 3 \\
\hline $\begin{array}{l}\text { Understanding the } \\
\text { means to be utilized } \\
\text { in leading the } \\
\text { examination }\end{array}$ & 3 & Agree & 64 & 4 \\
\hline $\begin{array}{l}\text { Distinguishing } \\
\text { analytical questions } \\
\text { in the assertion of } \\
\text { the issue }\end{array}$ & 3 & Agree & 64 & 4 \\
\hline $\begin{array}{l}\text { Decide the value of } \\
\text { the outcomes }\end{array}$ & 3 & Agree & 60 & 5 \\
\hline $\begin{array}{l}\text { Choosing the area } \\
\text { for the Research }\end{array}$ & 3 & Agree & 60 & 5 \\
\hline $\begin{array}{l}\text { Picking the } \\
\text { methodology or } \\
\text { exploration plan }\end{array}$ & 3 & Agree & 58 & 6 \\
\hline $\begin{array}{l}\text { Building up a } \\
\text { substantial and } \\
\text { reliable instrument }\end{array}$ & 3 & & 54 & 7 \\
\hline Overall Mode & & & & \\
\hline
\end{tabular}

Table V shows the Level of Assessment on the Complexity of setting up the proposition as uncovered by the respondents. It shows that pointer as to be acquainted with different scientists led in regions identified with specialization: recorded the most vital Mode at $72 \%$ and 
decoded as Agree, which suggests that the program markers were acted overall.

It infers that respondents experienced trouble regarding acquaintance with different investigative measures to territories identified with specialization.

An exploration proposition's objective is to introduce and legitimize the need to examine issues and teach handy manners by directing the proposed study (Krathwohl, 2005). Kim's (2018), doing a cautious and careful writing audit is essential when you expound on Research at any level.

It is necessary schoolwork that is accepted cautiously and a given certainty in all exploration papers.

It does not just study what exploration in the past on a subject. However, it also evaluates, exemplifies, thoroughly analyzes, and corresponds to different academic books, research articles, and other pertinent sources that identify the research flow.

The markers that build up a legitimate and dependable instrument got the least Mode at $54 \%$ and deciphered as Agree. It infers that a big part of the respondents experiences challenges in approving a reliable information gathering instrument.

As per Radhakrishna (2007), Questionnaires are the most generally utilized information assortment techniques in instructive and assessment Research.

It depicts the cycle for creating and testing polls and sets five consecutive advances associated with creating and testing a survey: research foundation, survey conceptualization, organization and information investigation, and setting up legitimacy and unwavering quality.

TABLE VI LEVEL OF ASSESSMENT ON THE COMPLEXITY ENCOUNTERED IN LEADING THE EXPLORATIONAS REVEALED BY THE RESPONDENTS.

\begin{tabular}{|l|c|c|c|c|}
\hline \multicolumn{1}{|c|}{ Complexity encountered in leading the exploration } & Mode & Interpretation & (\%) & Rank \\
\hline The pace of poll returns (recovery of the instrument) & 3 & Agree & 64 & 1 \\
\hline $\begin{array}{l}\text { Availability of archives, individuals, and foundations in } \\
\text { information gathering }\end{array}$ & 3 & Agree & 62 & 2 \\
\hline $\begin{array}{l}\text { The readiness of people or establishments to take an } \\
\text { interest or give data }\end{array}$ & 3 & Agree & 62 & 2 \\
\hline Information on the means of directing the exploration & 3 & Agree & 60 & 3 \\
\hline $\begin{array}{l}\text { Ampleness of information in estimating apparatuses } \\
\text { (insights) to evaluate and examine research information. }\end{array}$ & 4 & Strongly Agree & 54 & 4 \\
\hline the closeness of examination area/setting/climate & 3 & Agree & 50 & 5 \\
\hline $\begin{array}{l}\text { The measure of time accessible to lead and complete the } \\
\text { exploration }\end{array}$ & 3 & Agree & 48 & 6 \\
\hline Adequacy of monetary assets/reserves & 3 & Agree & 48 & 6 \\
\hline $\begin{array}{l}\text { Accessibility of examination assets (i.e., space, PCs and } \\
\text { other hardware, transportation, correspondence, and } \\
\text { different offices) }\end{array}$ & 3 & Agree & 46 & 7 \\
\hline $\begin{array}{l}\text { Accessibility of guide/warning council to react to } \\
\text { inquiries }\end{array}$ & 3 & Agree & 46 & 7 \\
\hline Overall Mode & 3 & Agree & & 7 \\
\hline
\end{tabular}

Table VI shows the outcomes on the Level of Assessment on the Complexity experienced in Conducting the Research as uncovered by the respondents.

As to marker, which is the Rate of survey returns (recovery of the instrument), got the most elevated Mode at $64 \%$ and deciphered as Agree.

It infers that the vast majority of the respondents experience trouble recovering the device, the review poll.

As indicated by Jones (2018), research needs in gathering information are significant. Investigated information permits scientists to survey, assess, or measure the factors remembered for the examination (Malin and Morrow (2009).
Reis (2000) enumerates that "The counsel is simply the essential guardian for the expert regard of the understudy, the pace of progress toward the degree, and admittance to future chances.

Schekman et al. (2015) expressing that apparatuses and Resources articles should thoroughly depict the organic material, information, and techniques so planned clients have all the data expected to send them inside their work. 
TABLE VII LEVEL OF ASSESSMENT ON THE COMPLEXITY OF COMPOSING THE RESEARCH PAPER ASREVEALED BY THE RESPONDENTS

\begin{tabular}{|l|c|c|c|c|}
\hline The complexity of composing the research paper & Mode & Interpretation & (\%) & Rank \\
\hline $\begin{array}{l}\text { Changing the proposition into a last examination } \\
\text { design }\end{array}$ & 3 & Agree & 70 & 1 \\
\hline $\begin{array}{l}\text { Introducing information precisely utilizing tables, } \\
\text { figures, or graphs }\end{array}$ & 3 & Agree & 70 & 1 \\
\hline $\begin{array}{l}\text { Depicting or outlining likenesses and contrasts in } \\
\text { discoveries or information }\end{array}$ & 3 & Agree & 62 & 2 \\
\hline Featuring critical findings or information & 3 & Agree & 60 & 3 \\
\hline $\begin{array}{l}\text { Examining the discoveries in the writing base's } \\
\text { setting looked into in Chapter 2, reasonable system, } \\
\text { research questions, and speculation. }\end{array}$ & 3 & Agree & 58 & 4 \\
\hline $\begin{array}{l}\text { Drawing suggestions which are possible, plausible, } \\
\text { conservative, practicable, proficient, or powerful } \\
\text { methods of taking care of the issue }\end{array}$ & 3 & Agree & 54 & 5 \\
\hline Deciphering or clarifying the information & 3 & Agree & 52 & 6 \\
\hline $\begin{array}{l}\text { Sorting out the introduction and translation of } \\
\text { discoveries }\end{array}$ & 3 & Agree & 52 & 6 \\
\hline Detailing conclusion compactly & 3 & Agree & 52 & 6 \\
\hline $\begin{array}{l}\text { Introducing thoughts intelligently, legitimately, } \\
\text { plainly, and carefully }\end{array}$ & 4 & $\begin{array}{c}\text { Strongly } \\
\text { Agree }\end{array}$ & 50 & 7 \\
\hline Overall Mode & 3 & Agree & & \\
\hline
\end{tabular}

Table VII shows the outcomes on the Level of Assessment on the Complexity experienced recorded as Changing the proposition into a final examination design as uncovered by the Respondents. It recorded a mode at $70 \%$ and deciphered as Agree. It infers that the vast majority of the respondents experienced trouble changing the proposition into a final examination design. It should be explicit because having a normalized research design is fundamental in accomplishing an examination paper's viability and proficiency.
According to Plaut (2013), some anticipatedsnares that understudies watch out for fall into reliably when forming are search paper. Checking these normal ensnarement's when making an assessment paper can help not submit these blunders (Andrews, 2005).

TABLE VIII SUMMARIZED DATA ON THE LEVEL OF ASSESSMENT AS PERCEIVED BY THE RESPONDENTS

\begin{tabular}{|l|c|c|c|c|}
\hline & Mode & Interpretation & $\mathbf{( \% )}$ & Rank \\
\hline Complexity in Setting up the proposition & 3 & Agree & 100 & 1 \\
\hline Complexity Encountered in leading the exploration & 3 & Agree & 90 & 2 \\
\hline $\begin{array}{l}\text { Complexity Encountered in composing the } \\
\text { research paper }\end{array}$ & 3 & Agree & 90 & 2 \\
\hline Significance of directing Research & 3 & Agree & 70 & 3 \\
\hline Grand Mode & 3 & Agree & & \\
\hline
\end{tabular}

Table VIII shows the outcomes on the Summarized information fair and square of appraisal as seen by the Respondents. Concerning Complexity in setting up the proposition, the respondents' entirety concurs that they experience multifaceted nature in setting up the proposition. Concerning Complexity Encountered in leading the exploration,it got a mode of $90 \%$ and unravelled as Agree.

Concerning Complexity Encountered in composing the research paper, it got a mode at $90 \%$. It deciphered likewise as Agree. Concerning the significance of Undertaking Research, it recorded a mode at $70 \%$ and deciphered as
Agree. The expressed markers inferred that most of the respondents do agree that they experience challenges in

Those regions. Yet what makes a difference most is that they take in out from the excursion of getting ready, leading and composing the Research paper and legitimize inside the setting of how significant directing exploration these days on scholarly inclination as well as an approach to develop and topping off the holes among information and practice.

As indicated by Diana et al. (2018), there are information holes among proof and practice concerning execution ideas' viability. 


\section{CONCLUSION}

Research is an essential zone in the field of guidance, just as unconcerned areas too. It sanitizes the activities and the lives of the people. It fundamentally centers on improving quality and is a quest for information. It tells the best way to arrange answers for issues logically and efficiently. The study concluded that Research is a significant part of understudies' learning cycle and a substantial part of the College undertaking. The investigation likewise uncovered that understudies broadly experienced complexities recorded as a hard copy of the proposition, leading the exploration, and composing the examination paper. Moreover, emphasis on the significance of Research among understudies is a thing to be perceived to persuade them to seek after Research, notwithstanding the troubles they may experience.

\section{TRANSLATIONAL RESEARCH}

The discoveries in this consecutive examination could be converted into a guide of systems and approaches to different college course programs. It draws the connection between counsel and understudies, revealing the essentialness of research. The theoretical ramifications attracted can be spread to use educating and learning modalities following Research endeavors.

\section{RECOMMENDATIONS}

The researcher proposed a Research Sustainable Intervention Plan to direct Research preparation and workshop each semester from the Program Research Coordinator to ingrain and spur understudies on the advantages they can get from investigating besides recognizing that it is only a course prerequisite to graduate. Research educators ought to embrace strategies and procedures dependent on Outcome Based Teaching and Learning to empower understudies. Staff counsels should investigate students' output and urge them to work intently to find what knowledge lacks. The College of Business and Accountancy ought to hold every semester Research Forum to propel understudies to do quality research. The college and its organizations ought to liberally uphold understudy needs in the wording of faculties and gear needed in doing an investigation. To lead further studies to decide other problems that may be experienced by understudies when they embrace Research.

\section{REFERENCES}

[1] Ahmad, Syed Shoeb. (2016). Research and Its Importance. The Ophthalmology - Open Journal. 1, Retrieved from https://bit.ly/3fnYYdj

[2] Ana Paula Cabral, Isabel Huet, (2011). Research In Higher Education: The Role Of Teaching And Student Learning, Procedia - Social and Behavioral Sciences, 29, 91-97. Retrieved from https://bit.ly/3pP18Yv

[3] Anderson, L., Krathwohl, D., \& Bloom, B. (2001). A taxonomy for learning, teaching, and assessing : a revision of Bloom's taxonomy of educational objectives/editors, Lorin W. Anderson, David
Krathwohl; contributors, Peter W. Airasian ... [et al.]. (Complete ed.). New York: Longman. Retrieved from https://bit.ly/2ZpSbuf

[4] Andrews J., (2005). Wheeling uphill? Reflections of practical and methodological difficulties encountered in researching the experiences of disabled volunteers. Disability \& Society, 20(2), 201-212. Retrieved from https://bit.ly/3fktEw4

[5] Bruner, J. (2019). Constructivist Theory (Jerome Bruner). Retrieved from https://bit.ly/2GEj7N9

[6] Chen, H. T. (2012). Theory-driven evaluation: Conceptual framework, application, and advancement. Retrieved from https://bit.ly/2IcO0sP

[7] Crowe, A., Dirks, C., \& Wenderoth, M. P. (2008). Biology in Bloom: Implementing Blooms Taxonomy to Enhance Student Learning in Biology. CBE-Life Sciences Education, 7(4), 368-381. Retrieved from https://bit.ly/396s6Vl

[8] David K. R. (2002). A Revision of Bloom's Taxonomy: An Overview, Theory Into Practice, 41(4), 212-218. Retrieved from https://bit.ly/35Qs2qQ

[9] Diana, C., Rasmussen, N., Højberg, H ., Bengtsen, E., \& Jørgensen. M.B. (2018). Identifying knnowledge gaps between practice and Research for implementation components of sustainable interventions to improve the working environment - A rapid review, Applied Ergonomics, 67, 178-192. Retrieved from https://bit.ly/35Qrtxe

[10] Donaldson, S. (2012). Strategies and Applications: Program Theory-Driven Evaluation Science.

[11] Hove, East Sussex BN3 2FA, New York: Routledge. Retrieved from https://bit.ly/2m4KjfJ

[12] Drugowitsch, J., Moreno-Bote, R., \& Pouget, A. (2014). The relation between Belief and Performance in Perceptual Decision Making. PLoS ONE, 9(5). Retrieved from https://bit.ly/3lUB4IX

[13] Duxbury, N., Bakas, F. E., \& Carvalho, C. P. D. (2019). Why is Research-practice collaboration so challenging to achieve? A creative tourism experiment. Tourism Geographies, 1-26. Retrieved from https://bit.ly/37cQaDN

[14] Education State University. (2019). Philippines - Educational System - an overview. Retrieved from https://bit.ly/2Fgb6fD

[15] Foster-Fishman, P. G., Nowell, B., \& Yang, H. (2007). Putting the system back into systems change: A framework for understanding and changing organizational and community structures. American Journal of Community Psychology, 39(3-4), 197-215. Retrieved from https://bit.ly/2KwtmXQ

[16] Funnell, C., \& Rogers, P. J. (2011). Purposeful Program Theory: Effective Use of Theories of Change and Logic Models. Retrieved from https://bit.ly/2kAyTzN

[17] Hope, S. (2016). Bursting paradigms: A color wheel of practiceresearch. Cultural Trends, 25(2), 74-86. Retrieved from https://bit.ly/3nIFAe8

[18] Jeannotte, M. S., \& Duxbury, N. (2015). Advancing knowledge through grassroots experiments: Connecting culture and sustainability. Journal of Arts Management, Law and Society, 45(2), 84-99. Retrieved from https://bit.ly/3nMEvC0

[19] Jones, R. (2018). Doctoral Research: The Importance of Reliable and Valid Data Collection Instrument. Retrieved from https://bit.ly/2kqRIW9

[20] Joosten, T., Harness, L., and Cusatis, R. (2016). Top 5 Challenges in Conducting Deta Research. The University of WisconsinMilwaukee. Retrieved from https://bit.ly/2wuFg9R

[21] Kapur, R. (2018). Significance of Research in Education. Retrieved from https://bit.ly/2kasGKY

[22] Kim, Y. S. (2018). The Importance of Literature Review in Research Writing. Murray State College. Retrieved from https://bit.ly/2mjWAND

[23] Kothari, C.R. (2004). Research Methodology: Methods and Techniques. New Age International. Limited. ISBN 9788122415223. Retrieved from https://bit.ly/2kodfPu

[24] Krathwohl, D. R. (2005). Research Guides: Organizing Your Social Sciences Research Paper: Writing a Research Proposal. Retrieved from https://bit.ly/2x5Ut2i

[25] Kuh, George D \& Hu, Shouping. (2001). "The effects of StudentFaculty Interaction In the 1990s." The Review of Higher Education, 24(3), 309-332. Project MUSE, Retrieved from https://bit.ly/331YnJB 
[26] Lanson, R. A. (2004). Undergraduate Research Projects and Dissertations: issues of topic selection, access, and data collection amongst tourism management students. The Journal of Hospitality Leisure Sport and Tourism,3(1), 19-32. Retrieved from https://bit.ly/3kNb5Ss

[27] Lassiter, L. E. (2005). The Chicago guide to collaborative ethnography. Chicago, IL. University of Chicago Press. Retrieved from https://bit.ly/2lOTMI3

[28] Maini, R., Jack, S. M., \& Borghi, J. (2017). How to and how not to develop a theory of change to evaluate a complex intervention: reflections on an experience in the Democratic Republic of Congo. BMJ Global Health Journals, 1(3). Retrieved from https://bit.ly/339PnSK

[29] Malin, N., \& Morrow, G. (2009). Evaluating the role of the Sure Start Plus Adviser in providing integrated support for pregnant teenagers and young parents. Health \& Social Care in the Community, 17(5), 495-503. Retrieved from https://bit.ly/3nK6JNH

[30] Mead, M. (2019). What is Systems Theory? Environment and Ecology. Retrieved from https://bit.ly/2IntVzx

[31] Miller, D. (2017). Importance of School Monitoring And Evaluation Systems. Retrieved from https://bit.ly/2BKbxQ3

[32] Oldfield, B., \& Baron, S. (2000). Student perceptions of service quality in a UK university business and management faculty, Quality Assurance in Education, 8(2), pp. 85-95. Retrieved from https://bit.ly/3947ahS

[33] Plaut, D. (2013). Common Mistakes to Avoid When Writing a Research Paper. Retrieved from https://bit.ly/2kybxuU

[34] Pramodini D. K. \& Anu Sophia (2012). Evaluation Of Importance For Education Research. International Journal of Social Science \& Interdisciplinary Research, 1(9). Retrieved from https://bit.ly/2Kny89S

[35] Rama B. Radhakrishna (2007). Tips for Developing and Testing Questionnaires/Instruments.

[36] The Pennsylvania State University University Park, Pennsylvania, Extension Journal, Inc. ISSN 1077-5315 Retrieved from https://bit.ly/2PpiY5X

[37] Reddy, C. (2019). Why Research is Important for Students, Humans, Education. Wistestep. Retrieved from https://bit.ly/2DpFfJU

[38] Reis, R. M. (2000). Choosing The Right Research Adviser. Retrieved from https://bit.ly/2lQQGDp

[39] Roulstone, S. E., Marshall J. E., \& Powell G.G. (2015). Program Grants for Applied Research, No. 3.5., Evidence-based intervention for preschool children with primary speech and language impairments: Child Talk - an exploratory mixed-methods study. NIHR Journals Library Southampton (UK). Retrieved from https://bit.ly/2IlTzVs

[40] Sekaran, U. \& Bougie, R. (2016). Research Methods For Business: A Skill Building Approach, abridged, illustrated. John Wiley \& Sons, 2016. ISBN 9781119165552. Retrieved from https://bit.ly/2m4IzTJ

[41] Schekman, R., Weigel, D., \& Watt, F. M. (2015). Recognizing the importance of new tools and resources for Research. E Life Sciences Publications, Ltd, e07083. Retrieved from https://bit.ly/3kSO40v

[42] Siu, E. (2017). Small Business Heroes. This Is Why You Should Consider Getting a Degree in Marketing. Retrieved from https://bit.ly/2k1veJu

[43] Story, J. (2013). The Role of Academic Research in Student Learning. Cameron School of Business, University of. Thomas. Retrieved from https://bit.ly/2klTiss

[44] Teknomo, K (2006). What are Belief, Perception, and Attitude?. Retrieved fromhttps://bit.ly/3foyizz

[45] Umbach, P. D., \& Wawrzynski, M. R. (2005). Faculty do Matter: The Role of College Faculty in Student Learning and Engagement. Research in Higher Education, 46(2), 153-184. Retrieved from https://bit.ly/2IPDIXT

[46] Weiss, J. W. (2019). What is Theory of Change? The Center Theory of Change. Retrieved from https://bit.ly/2AItewn 